\title{
Front Matter: Volume 8951
}

, "Front Matter: Volume 8951," Proc. SPIE 8951, Optical Diagnostics and Sensing XIV: Toward Point-of-Care Diagnostics, 895101 (18 March 2014); doi: 10.1117/12.2052765

SPIE. Event: SPIE BiOS, 2014, San Francisco, California, United States 


\section{PROGRESS IN BIOMEDICAL OPTICS AND IMAGING}

\section{Optical Diagnostics and Sensing XIV: Toward Point-of-Care Diagnostics}

\section{Gerard L. Coté}

Editor

3 and 5-6 February 2014

San Francisco, California, United States

Sponsored and Published by

SPIE 
The papers included in this volume were part of the technical conference cited on the cover and title page. Papers were selected and subject to review by the editors and conference program committee. Some conference presentations may not be available for publication. The papers published in these proceedings reflect the work and thoughts of the authors and are published herein as submitted. The publisher is not responsible for the validity of the information or for any outcomes resulting from reliance thereon.

Please use the following format to cite material from this book:

Author(s), "Title of Paper," in Optical Diagnostics and Sensing XIV: Toward Point-of-Care Diagnostics, edited by Gerard L. Coté, Proceedings of SPIE Vol. 8951 (SPIE, Bellingham, WA, 2014) Article CID Number.

ISSN: 1605-7422

ISBN: 9780819498649

Published by

SPIE

P.O. Box 10, Bellingham, Washington 98227-0010 USA

Telephone +1 3606763290 (Pacific Time) · Fax +1 3606471445

SPIE.org

Copyright (C) 2014, Society of Photo-Optical Instrumentation Engineers.

Copying of material in this book for internal or personal use, or for the internal or personal use of specific clients, beyond the fair use provisions granted by the U.S. Copyright Law is authorized by SPIE subject to payment of copying fees. The Transactional Reporting Service base fee for this volume is $\$ 18.00$ per article (or portion thereof), which should be paid directly to the Copyright Clearance Center (CCC), 222 Rosewood Drive, Danvers, MA 01923. Payment may also be made electronically through CCC Online at copyright.com. Other copying for republication, resale, advertising or promotion, or any form of systematic or multiple reproduction of any material in this book is prohibited except with permission in writing from the publisher. The CCC fee code is $1605-7422 / 14 / \$ 18.00$.

Printed in the United States of America.

Publication of record for individual papers is online in the SPIE Digital Library.

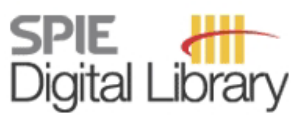

SPIEDigitalLibrary.org

Paper Numbering: Proceedings of SPIE follow an e-First publication model, with papers published first online and then in print and on CD-ROM. Papers are published as they are submitted and meet publication criteria. A unique, consistent, permanent citation identifier (CID) number is assigned to each article at the time of the first publication. Utilization of CIDs allows articles to be fully citable as soon as they are published online, and connects the same identifier to all online, print, and electronic versions of the publication. SPIE uses a six-digit CID article numbering system in which:

- The first four digits correspond to the SPIE volume number.

- The last two digits indicate publication order within the volume using a Base 36 numbering

system employing both numerals and letters. These two-number sets start with 00, 01, 02, 03, 04, $05,06,07,08,09,0 A, 0 B \ldots 0 Z$, followed by 10-1Z, 20-2Z, etc.

The CID Number appears on each page of the manuscript. The complete citation is used on the first page, and an abbreviated version on subsequent pages. Numbers in the index correspond to the last two digits of the six-digit CID Number. 


\section{Contents}

vii Conference Committee

\section{SESSION 1 PERFUSION AND OXYGENATION IMAGING AND MONITORING}

895102 A simple and robust optical scheme for self-mixing low-coherence flowmeters [8951-1]

S. Cattini, L. Rovati, Univ. degli Studi di Modena e Reggio Emilia (Italy)

895103 Photoplethysmography beyond perfusion and oxygenation monitoring: pulse wave analysis for hepatic graft monitoring [8951-2]

T. J. Akl, Texas A\&M Univ. (United States); M. A. Wilson, Univ. of Pittsburgh (United States) and VA Pittsburgh Healthcare System (United States); M. N. Ericson, Oak Ridge National Lab. (United States); G. L. Coté, Texas A\&M Univ. (United States)

895106 High resolution coherence domain depth-resolved nailfold capillaroscopy based on correlation mapping optical coherence tomography [8951-5]

H. M. Subhash, S. O'Gorman, K. Neuhaus, National Univ. of Ireland, Galway (Ireland); M. Leahy, National Univ. of Ireland, Galway (Ireland) and Royal College of Surgeons (Ireland)

\section{SESSION 2 SENSING OF GLUCOSE AND OTHER BLOOD ANALYTES}

895107 Modeling the optical coupling across the anterior chamber of the eye towards polarimetric glucose sensing [8951-6]

C. W. Pirnstill, G. L. Coté, Texas A\&M Univ. (United States)

895108 Influence of spectral bandwidth limitations of tuneable external-cavity based quantum cascade laser systems for clinical biofluid analysis [8951-7]

H. M. Heise, T. Vahlsing, South-Westphalia Univ. of Applied Sciences (Germany)

895109 Blood analyte sensing using fluorescent dye-loaded red blood cells [8951-8]

S. C. Ritter, Texas A\&M Univ. (United States); X. Shao, N. Cooley, M. A. Milanick, T. E. Glass, Univ. of Missouri-Columbia (United States); K. E. Meissner, Texas A\&M Univ. (United States)

8951 OA ConA-based glucose sensing using the long-lifetime azadioxatriangulenium fluorophore [8951-9]

B. Cummins, Texas A\&M Univ. (United States) and Univ. of Strathclyde (United Kingdom);

J. Simpson, Univ. of Strathclyde (United Kingdom); Z. Gryczynski, Texas Christian Univ.

(United States); T. J. Sørensen, B. W. Laursen, Univ. of Copenhagen (Denmark); D. Graham,

D. Birch, Univ. of Strathclyde (United Kingdom); G. Coté, Texas A\&M Univ. (United States) 
8951 OB Blood cell diagnostics by a chip lensless microscope [8951-10]

R. Riesenberg, M. Kanka, G. Mayer, Leibniz Institute of Photonic Technology (Germany)

8951 OC An optical cavity based biosensor with chained differential detection to improve sensitivity and fabrication tolerance [8951-11]

J. Brake, S. Kim, LeTourneau Univ. (United States)

8951 OD Fluorescent imaging over an ultra-large field-of-view of $532 \mathbf{c m}^{2}$ using a flatbed scanner [8951-12]

Z. S. Göröcs, Y. Ling, M. D. Yu, D. Karahalios, K. Mogharabi, K. LU, Q. Wei, A. Ozcan, Univ. of California, Los Angeles (United States)

8951 OF Rapid identification of bacterial resistance to Ciprofloxacin using surface-enhanced Raman spectroscopy [8951-14]

E. Kastanos, Univ. of Nicosia (Cyprus); K. Hadjigeorgiou, C. Pitris, Univ. of Cyprus (Cyprus)

\section{SESSION 4 GLOBAL POINT-OF-CARE APPLICATIONS AND SYSTEMS}

$8951 \mathrm{OH} \quad$ Stick-on microscope for smartphones [8951-16]

W. M. Lee, The Australian National Univ. (Australia)

8951 Ol Universal lab on a smartphone: a research of TiOPc thin film as a light dependence electrode [8951-17]

P. Lin, Y. H. Hsu, C. K. Lee, National Taiwan Univ. (Taiwan)

$89510 \mathrm{~J}$ Dual-wavelength excitation to reduce background fluorescence for fluorescence spectroscopic quantitation of erythrocyte zinc protoporphyrin-IX and protoporphyrin-IX from whole blood and oral mucosa [8951-18]

G. Hennig, M. Vogeser, L. M. Holdt, C. Homann, M. Großmann, H. Stepp, C. Gruber, I. Erdogan, S. Hasmüller, U. Hasbargen, Klinikum der Univ. München (Germany);

G. M. Brittenham, Columbia Univ. College of Physicians and Surgeons (United States)

8951 OK Point-of-care optical tool to detect early stage of hemorrhage and shock [8951-19] R. S. Gurjar, S. L. Riccardi, Radiation Monitoring Devices, Inc. (United States); B. D. Johnson, C. P. Johnson, Mayo Clinic (United States); N. A. Paradis, Dartmouth-Hitchcock Medical Ctr. (United States); M. J. Joyner, Mayo Clinic (United States); D. E. Wolf, Radiation Monitoring Devices, Inc. (United States)

\section{SESSION 5 CANCER DETECTION USING OPTICAL TECHNIQUES}

$8951 \mathrm{OM}$ In vivo and in vitro hyperspectral imaging of cervical neoplasia [8951-22]

C. Wang, W. Zheng, Univ. of Science and Technology of China (China); Y. Bu, The 105th PLA Hospital (China); S. Chang, Chongqing Medical Univ. (China); Q. Tong, The 105th PLA Hospital (China); S. Zhang, R. X. XU, Univ. of Science and Technology of China (China) 
8951 ON Measurement of the human esophageal cancer in an early stage with Raman spectroscopy [8951-24]

Y. Maeda, M. Ishigaki, A. Taketani, B. B. Andriana, Kwansei Gakuin Univ. (Japan);

R. Ishihara, Osaka Medical Ctr. for Cancer and Cardiovascular Diseases (Japan); H. Sato, Kwansei Gakuin Univ. (Japan)

895100 Raman endoscopy for real time monitoring of anticancer drug treatment in colorectal tumors of live model mice [8951-25]

A. Taketani, M. Ishigaki, B. B. Andriana, H. Sato, Kwansei Gakuin Univ. (Japan)

SESSION 6 DRUG IDENTIFICATION, ANALYSIS, AND TRACKING

8951 OP Multi-wavelength pulse plethysmography for real-time drug delivery monitoring [8951-27]

P. Adhikari, I. B. Magaña, P. D. O'Neal, Lovisiana Tech Univ. (United States)

\section{POSTER SESSION}

8951 OS Characterization of BxPC3-transplanted mice by hyperspectral autofluorescence imaging and Raman spectroscopy [8951-23]

M. Sawa, B. B. Andriana, H. Sato, Kwansei Gakuin Univ. (Japan)

8951 OU Novel noninvasive point-of-care device for real time hemoglobin monitoring [8951-31] U. Timm, H. Gewiss, J. Kraitl, Univ. Rostock (Germany); K. Stuepmann, German Red Cross Blood Donation Service (Germany); M. Hinz, S. Koball, H. Ewald, Univ. Rostock (Germany)

8951 OW Optical clearing method for monitoring cutaneous microcirculation response to vasoactive drugs with high sensitivity [8951-33]

R. Shi, M. Chen, R. Wang, C. Ma, J. Jin, Y. Lu, Huazhong Univ. of Science and Technology (China); P. Timoshina, V. V. Tuchin, N.G. Chernyshevsky Saratov State Univ. (Russian Federation); D. Zhu, Huazhong Univ. of Science and Technology (China)

8951 0X Pilot study to visualise and measure skin tissue oxygenation, erythema, total haemoglobin and melanin content using index maps in healthy controls [8951-34]

I. Poxon, The Univ. of Manchester (United Kingdom); J. Wilkinson, Salford Royal NHS Foundation Trust (United Kingdom); A. Herrick, Manchester Academic Health Science Ctr. (United Kingdom); M. Dickinson, The Univ. of Manchester (United Kingdom); A. Murray, Manchester Academic Health Science Ctr. (United Kingdom)

8951 OY Quantitative measurement of biological substances in daily-life environment with the littlefinger-size one-shot spectroscopic tomography [8951-35]

A. Ishida, S. Sato, S. Nakada, S. Suzuki, P. K. W. Abeygunawardhana, K. Wada,

A. Nishiyama, I. Ishimaru, Kagawa Univ. (Japan)

$89510 Z$ Wide-field spectroscopic imaging of biological-substance distributions on entire faces by measuring middle infrared lights emitted from human bodies itself [8951-36]

Y. Suzuki, W. Qi, M. Fujiwara, H. Hiramatsu, S. Suzuki, P. Abeygunawardhana, K. Wada,

A. Nishiyama, I. Ishimaru, Kagawa Univ. (Japan) 
895110 A demonstration of multiplex biosensing using whispering gallery mode microspheres positioned onto a microstructured optical fiber tip [8951-38]

T. Reynolds, A. François, The Univ. of Adelaide (Australia); S. J. Nicholls, South Australian Health and Medical Research Institute (Australia); T. M. Monro, The Univ. of Adelaide (Australia)

895111 High-speed dual-wavelength optical polarimetry for glucose sensing [8951-39]

D. T. Grunden, C. W. Pirnstill, G. L. Coté, Texas A\&M Univ. (United States)

895112 PEGylation of Concanavalin A to decrease nonspecific interactions in a fluorescent glucose sensor [8951-40]

A. A. Abraham, B. M. Cummins, A. K. Locke, M. A. Grunlan, G. L. Coté, Texas A\&M Univ. (United States)

895113 Multimodal assessment of spatial distribution of drug-tracer uptake by brain tissue after intra-arterial injections [8951-41]

R. Singh-Moon, Columbia Univ. Medical Ctr. (United States); D. Chaudhuri, Boston Univ. (United States); M. Wang, Columbia Univ. Medical Ctr. (United States); R. Straubinger, Univ. at Buffalo (United States); I. J. Bigio, Boston Univ. (United States); S. Joshi, Columbia Univ. Medical Ctr. (United States)

895114 Developing strategies to enhance loading efficiency of erythrosensors [8951-42]

S. C. Bustamante Lopez, S. C. Ritter, K. E. Meissner, Texas A\&M Univ. (United States)

Author Index 


\section{Conference Committee}

Symposium Chairs

James G. Fujimoto, Massachusetts Institute of Technology (United States)

R. Rox Anderson, Wellman Center for Photomedicine, Massachusetts General Hospital (United States) and Harvard School of Medicine (United States)

Program Track Chairs

Ammasi Periasamy, University of Virginia (United States)

Daniel L. Farkas, University of Southern California (United States)

Conference Chair

Gerard L. Coté, Texas A\&M University (United States)

Conference Program Committee

Brent D. Cameron, The University of Toledo (United States)

Werner Gellermann, The University of Utah (United States)

Jürgen M. Lademann, Charité Universitätsmedizin Berlin (Germany)

Kristen C. Maitland, Texas A\&M University (United States)

Michael J. McShane, Texas A\&M University (United States)

Kenith E. Meissner, Texas A\&M University (United States)

Babak Shadgan M.D., The University of British Columbia (Canada)

Kexin Xu, Tianjin University (China)

Shaoqun Zeng, Britton Chance Center for Biomedical Photonics (China)

Session Chairs

1 Perfusion and Oxygenation Imaging and Monitoring

Babak Shadgan M.D., The University of British Columbia (Canada)

2 Sensing of Glucose and Other Blood Analytes

Michael J. McShane, Texas A\&M University (United States)

3 Point-of-Care Sensing and Imaging

Aydogan Ozcan, University of California, Los Angeles (United States)

4 Global Point-of-Care Applications and Systems

Kristen C. Maitland, Texas A\&M University (United States)

5 Cancer Detection Using Optical Techniques

Daniel S. Gareau, The Rockefeller University (United States) 
6 Drug Identification, Analysis, and Tracking

Patrick D. O'Neal, Louisiana Tech University (United States)

Proc. of SPIE Vol. $8951895101-8$

Downloaded From: https://www.spiedigitallibrary.org/conference-proceedings-of-spie on 26 Apr 2023 Terms of Use: https://www.spiedigitallibrary.org/terms-of-use 